\title{
HEALTH STATUS AND LIFE SATISFACTION OF PROFESSIONALLY ACTIVE AND PROFESSIONALLY INACTIVE INDIVIDUALS AMONG THE RETIRED PEOPLE
}

\author{
Mohini Tyagi ${ }^{1}$ and Seema Singh ${ }^{2}$ \\ ${ }^{1}$ MA scholar of Master of Arts in Psychology Specializing in Organizational Behavior at Amity \\ University, Uttar Pradesh Noida, India \\ ${ }^{2}$ Assistant Professor at Amity Institute of Behavioral Health And Allied Science (Aibhas) Amity \\ University, Uttar Pradesh Noida, India \\ DOI: 10.46609/IJSSER.2021.v06i02.018 URL: https://doi.org/10.46609/IJSSER.2021.v06i02.018
}

\begin{abstract}
This study assessed the health status and life satisfaction of professionally active and professionally inactive individuals among the retired people. The total sample size is taken 30 . The sample of 15 professionally active and 15 professionally inactive individuals were taken among the retired people who were earlier in public sector jobs. People who were still engaged in some work after their retirement were taken as the sample of professionally active and people who were not engaged in any work were taken as the sample of professionally inactive. Purposive sampling was done because the aim of the study was to assess the health status and life satisfaction of professionally active and professionally inactive among the retired people. The study tried to find whether there exists a difference in life satisfaction and health status amongst the professionally active and professionally inactive individuals. Professionally active aged population were found to be higher on psychological health.
\end{abstract}

\section{INTRODUCTION}

Ageing is irreversible biological changes that occur in all living things with the passage of time, eventually resulting in death. Although all organisms age, but rates of ageing vary considerably. Among humans, the effects of ageing vary from one individual to another as well as from one culture to another.

In 1950, the world population aged 60 years and above was 205 million (8.2 per cent of the population) which increased to 606 million (10 per cent of the population) in 2000 . By 2050, the proportion of older persons 60 years and above is projected to rise to 21.1 per cent, which will be two billion in number. Asia has the largest number of world's elderly ( 53 per cent), followed by 


\section{International Journal of Social Science and Economic Research}

ISSN: $2455-8834$

Volume:06, Issue:02 "February 2021"

Europe (25 per cent). This pressure of increasing numbers of elderly will intensify in the next 50 years. In 2050, 82 per cent of the world's elderly will be in developing regions of Asia, Africa,Latin America and the Caribbean while only 16 per cent of them will reside in the developed regions of Europe and North America. Population ageing is therefore rapidly emerging as the problem of developing countries. Ageing was not only an Asian trend up until 2000, but it is going to continue to dominate Asia in the next century as well (UNFPA, 1999).

Old age presents its special and unique problems but these have been aggravated due to the extraordinary speed of socioeconomic transformation leading to a number of changes in different aspects of living conditions. The needs and problems of the elderly vary significantly according to their age, socioeconomic status, health, living status and other such background characteristics (R. Siva, 2002). For elders living with their families - still the dominant living arrangement their economic security and well-being largely depends on the economic capacity of the family unit (Alam, 2006). In traditional Indian society, the informal support systems of family, relationship and community are considered strong enough to provide social security to its members, including older people. Urbanisation, industrialisation and the ongoing phenomenon of globalisation have cast their shadow on traditional values and norms within society. Gradual nuclearisation of the joint family, corrosion of morality in economy, changes in the value system, migration of youth to urban areas for jobs or work and increasing participation of women in the workforce are important factors responsible for the marginalisation of older people in rural India. As a result, the elderly depend on 'money-order economy' and their intimacy with their children is only from a distance (Vijaykumar, 1999). The many physiological, economic, emotional and interpersonal facets of ageing influence the social functioning and well-being of individuals in different ways. Changing traditional values, mobility of the younger generation, changes in family structure and role of women have contributed to a 'crisis in caring' for the elderly (Prakash,2004). Many facets of the generation gap contribute to marginalisation of older persons and their wisdom by the younger generation, leading to conflicts, lack of respect and decline of authority, neglect and sometimes even exploitation or abuse.

Given the rate of population ageing that developing countries like India are experiencing, there is a need to focus on ageing issues and to take effective measures for improvement in the quality of life of elderly in general and elderly women in particular. A country as large and complex as India needs to work out an extensive plan for the care and well-being of the elderly as necessary according to differences in levels of urbanisation as well as in cultural and familial systems. The rural poor, who mostly work in the informal or unorganised sector face insecure employment, insufficient income, and lack access to any form of social security and good quality and affordable health care. Generally, they have to pay a large percentage of their income for even basic healthcare services. As the interrelation of health and economic status continues throughout 


\section{International Journal of Social Science and Economic Research}

ISSN: $2455-8834$

Volume:06, Issue:02 "February 2021"

one's life, it is of special importance among the elderly whose livelihood depends on their physical ability and who do not have any provision for economic security, Social security pensions, though scanty in amount, create a sense of financial security for the elderly, who benefit through schemes such as old age pension, widow's pension, agricultural pension and pension for informal sector workers. However, the proportion of elderly who benefit from these schemes has to be improved significantly.

\section{Health conditions and ageing}

It is obvious that people become more and more vulnerable to chronic diseases, physical disabilities and mental incapacities in their old age. As age advances, due to declining physiological conditions, the body becomes more prone to illness. The illnesses of the elderly are multiple and chronic in nature. Arthritis, rheumatism, heart problems and high blood pressure are the most prevalent chronic diseases affecting them. Some of the health problems of the elderly can be attributed to social values also. The idea that old age is an age of ailments and physical infirmities is deeply rooted in the Indian mind and many of the sufferings and physical troubles which are curable are accepted as natural and inevitable by the elderly. Regarding the health problems of the elderly of different socioeconomic status, it was found (S. Raju, 2002) that while the elderly poor largely describe their health problems, on the basis of easily identifiable symptoms, like chest pain, shortness of breath, prolonged cough, breathlessness/ asthma, eye problems, difficulty in movements, tiredness and teeth problems, the upper class elderly, in view of their greater knowledge of illnesses, mentioned blood pressure, heart attacks, and diabetes which are largely diagnosed through clinical examination. In a study by (Mutharayappa and Bhat, 2008) NFHS-2 data was analysed to examine the type of lifestyle adopted by the elderly and its effects on their health conditions. "It was found that lifestyle adversely affects health and increases morbidity conditions among the elderly. Lifestyle habits such as alcohol consumption, regular smoking and tobacco chewing have adverse effects on one's ability to control diseases."

As early as (Gore,1990) while analysing the social factors affecting the health of the elderly, concluded that, "While there are no data showing direct relationship between income level and health of elderly individuals, one would assume that the nutritional and clinical care needs of the elderly are better met with adequate income than without it. If so, the poor countries and the poorer segments of the elderly population within each country would experience problems of health and well-being". In a study (Wason and Jain, 2011) of 962 elderly persons aged 60 and above in Jodhpur city, it was found that nearly 50 per cent of the subjects were at risk of malnutrition in low income group which was higher than the high income (29.5 per cent) and middle income groups (33.3 per cent). It was also observed that respondent's age and income significantly affect the Mini-Nutritional Assessment scores of the aged population. The main area of concern among the elderly is their health, which can in turn have a significant impact on 


\section{International Journal of Social Science and Economic Research}

ISSN: $2455-8834$

Volume:06, Issue:02 "February 2021"

their economic security, level of independence and social interaction. The analysis of NSS data by (Rajan, Risseeuw\&Perera) revealed a huge majority (70 per cent) of the elderly reporting their health status to be ranging from "excellent" to "good/fair" while around a quarter of the elderly reported their current health to be poor. Previous analysis has uncovered that such a high percentage of positive assessment of health status was despite a large number of the elderly reporting to be suffering from at least one disability or chronic ailment. Their analysis throws light on the difference in self-reported health status across sex. Despite the female disadvantage in reported health status and preponderance of older women among immobile elderly, a much greater proportion of men are hospitalised as compared to their female counterparts (87 vs. 67 per 1000). The diseases among the elderly for which there are more hospitalised cases than the rest are heart diseases, cataract and bronchial asthma. Based on the observations made on the health status of India's elderly, it can be concluded that some definite health intervention is necessary to cater to specific complications in old age (Rajan, Risseeuw\& Pereira, 2008).

In addition, an investigation carried out by (Devi\&Premakumar, 2000) have brought to light that elderly members are confronted with various nutritional, physiological and other general problems. The rural elderly are mostly illiterate with low income. They suffer from more nutritional, physiological and other problems. The men are more literate, economically independent and face less physiological and nutritional problems as compared to their female counterparts. When the literacy level, income level and employment status improve, they seem to be more comfortable with their health conditions and living status.

Some clinical studies have found that multiplicities of diseases are normal among the elderly and that a majority of the old are often ill with chronic bronchitis, anaemia, hypertension, digestive troubles, rheumatism, scabies and fever (Mutharayappa and Bhat, 2008). Some of the cases of disability among the elderly, as reported by a few medical studies, are difficulty in walking and standing, partial or complete blindness, partial deafness and difficulty in moving some joints, indigestion and mild breathlessness. The differential ageing phenomena, both physical and mental, appear to depend on environmental and social factors such as diet, type of education, adjustment to family and professional life.

Mental health of the elderly is another important factor in understanding their overall health situation. It is generally expected that the elderly should be free from mental worries since they have already completed their share of tasks and should lead a peaceful life. But often the unfinished familial tasks like education of children, marriage of daughter(s), etc. become a source of worry over a period of time. It is noticed (Raju, 2002) that the worries among the poor are usually about inadequate economic support, poor health, inadequate living space, loss of respect, unfinished familial tasks, lack of recreational facilities and the problem of spending time. In an epidemiological study on dementia in Maharashtra (Saldanhaet al., 2010), with 2145 


\section{International Journal of Social Science and Economic Research}

ISSN: $2455-8834$

Volume:06, Issue:02 "February 2021"

randomly selected respondents, the prevalence of dementia in the community was seen to be 4.1 per cent and the risk of dementia increases more than five-fold in the oldest old. It is clear from the above review of earlier studies on health of the elderly that the health and wellbeing of the elderly are affected by many interwoven aspects of their social and physical environment. Family support is found to be an important factor for socio-psychological well- being of the elderly (Devi and Murugesan, 2006). These range from their lifestyle and family structure to social and economic support systems, to the organisation and provision of health care. The pattern of various inputs for developing the appropriate social policy for the welfare of the elderly may have to be suitably modified in view of the diversity of the factors and their differential influence on the living conditions of the elderly.

\section{Retirement}

The meaning of retirement is usually bound up with the receipt of a pension - which is precisely why retired people are frequently referred to as 'pensioners'. In fact, it is often claimed that pensions precede retirement in a historical sense. Until Otto vonBismarck's government gave birth to the first state pension in Germany in the 1880s, people generally worked until death. In practice, however, ill-health often prohibited work in the final years of life, leading to a reliance on younger relatives for support; and the wealthiest members of society obviously felt the compulsion to continue working far less (Meadows, 2003). Bismarck himself only reluctantly retired at age 75, having fallen out of favour with Kaiser Wilhelm II; in any case, he would not have qualified for a pension, given that it was available only to industrial workers, and introduced primarily to stem support for socialism (Bonoli, 2000).

Workers who successfully plan for retirement tend to seek out formal planning methods such as retirement calculators, retirement seminars, and financial experts, instead of relying on advice from relatives or co-workers (Lusardi \& Mitchell, 2011a). Research supports a variety of approaches to improving individuals' level of information about financial concepts and motivation to plan, which may in turn contribute to their ability to plan and save for retirement:

a) Workplace Education. Both participation in and contributions to retirement savings plans are significantly higher when employers offer informational seminars (Bayer,Bernheim, \&Scholz, 2009). Workplace seminars appeared to have the most impact on the savings decisions of lowerwage workers and those who save the least. More frequent seminars affect savings behaviour more; written materials such as newsletters or plan summaries have little impact regardless of how frequently they were distributed. To be effective, seminars should not rely on a "one-sizefits-all" approach but take into account different preferences, economic circumstances, and levels of financial understanding (Lusardi, 2009). But the full impact of retirement seminars offered by employers is difficult to measure because workers who attend seminars may be more interested 


\section{International Journal of Social Science and Economic Research}

ISSN: $2455-8834$

Volume:06, Issue:02 "February 2021"

in planning than other workers, and employers may offer seminars because they have a largerthan-average share of workers who do little or no saving.

b) Workplace Processes. Automatic enrolment in employer provided pension plans leads to increases in pension participation. A study found that a planning form distributed to new hires during employee orientation tripled pension plan contributions. The form broke the enrolment process into seven steps and provided information such as the minimum and maximum allowable employee contribution to the pension plan (Lusardi, Keller, and Keller 2009). Another workplace approach, which gave employees information on the average pension savings levels of coworkers, led to increased savings among non-union employees but decreased contributions among union employees, who may not think employers act in their best interest (Beshears et al. 2011).

c) Psychological Factors. Financial education programs that include concrete goal-setting exercises are more likely to motivate individuals to plan (Stawski, Hershey, and Jacobs-Lawson 2007). Hershfield and colleagues (2011) suggest that virtual reality tools be incorporated in retirement planning and saving programs because consumers are more likely to follow through "on self-control tasks when they are fun and engaging."

\section{Professionally active and professionally inactive after retirement}

According to my research professionally active after retirement are those who are engaged in some work in their old age due to any reasons. Professionally inactive are those who are not engaged in any type of work due to any reason.

Healthy ageing is therefore much more than increasing the number of healthy life-years without any activity limitation and disability or disease. It has been briefly defined as the process of optimising equal opportunities for health to enable older people to take an active part in society and to enjoy an independent and good quality of life.

WHO Policy Framework on Active Ageing (2002)in order to achieve the ultimate goal of healthy ageing and active ageing, the WHO has developed a policy framework which focuses on areas such as preventing and reducing the burden of disabilities, chronic disease and premature mortality; reducing the risk factors associated with non-communicable diseases and functional decline as individuals age, while increasing factors that protect health; enacting policies and strategies that provide a continuum of care for people with chronic illness or disabilities; providing training and education to formal and informal carers; ensuring the protection, safety and dignity of ageing individuals; and enabling people as they age to maintain their contribution to economic development, to activity in the formal and informal sectors, and to their communities and families. 
International Journal of Social Science and Economic Research

ISSN: 2455-8834

Volume:06, Issue:02 "February 2021"

According to the findings of (Willis\& Shaffer, 1998)study indicate that factors in three domains differentiated highly competent faculty who planned to remain active following retirement and those who did not. First, there appear to be differences in personality characteristics. Those who planned to remain professionally active perceived themselves to be particularly constant with regard to work oriented activities and to feel the need to endure or persist at solving the task or problem at hand. In Contrast, those less Concerned with professional activities following retirement reported themselves to be higher on affiliative needs.

Second, the two groups can be differentiated on the basis of their Current professional activities. Those planning to remain professionally active in retirement currently spend a greater proportion of time in research. The larger number of hours currently spent in research may suggest a greater commitment to certain research questions that they plan to continue addressing in retirement.

Third, the groups differ in their retirement plans and their attitudes toward retirement. The involved group were more likely to view retirement as involving a "social stigma." This finding further supports the view of this group as being very work oriented and professionally committed. Perceptions of retirement as disengagement from work or involving a loss of the work role were viewed negatively by this group. For the other group, retirement is viewed as an opportunity to engage in alternative leisure activities and possibly to relocate to a new geographical location. This retirement plans appear congruent with their personality style of high affiliative needs.

\section{Health status among older people}

"Healthy aging is the development and maintenance of optimal mental, social, and physical wellbeing and function in older adults. This will most likely be achieved when communities are safe, promote health and well-being and use health services and community programs to prevent or minimize disease."

Principles were developed to complement the working definition and framework for healthy aging. These principles include:

- Respecting Minnesota's growing cultural diversity and including minority population viewpoints in conversations about Minnesota's aging population.

- Recognizing that health has many dimensions and is manifest through the interrelationship of mental, social and physical components. 


\section{International Journal of Social Science and Economic Research}

ISSN: 2455-8834

Volume:06, Issue:02 "February 2021"

- Appreciating the social determinants of health that affect people as they age including socioeconomic status, physical and social environments, and social stressors such as discrimination and ageism.

It is obvious that people become more and more susceptible to chronic diseases, physical disabilities and mental incapacities in their old age. As age advances, due to deteriorating physiological conditions, the body becomes more prone to illness. The illnesses of the elderly are multiple and chronic in nature. Arthritis, rheumatism, heart problems and high blood pressure are the most prevalent chronic diseases affecting them. Some of the health problems of the elderly can be attributed to social values also. The idea that old age is an age of ailments and physical infirmities is deeply rooted in the Indian mind and many of the sufferings and physical troubles which are curable are accepted as natural and inevitable by the elderly. Regarding the health problems of the elderly of different socioeconomic status, it was found (S.Raju, 2002) that while the elderly poor largely describe their health problems, on the basis of easily identifiable symptoms, like chest pain, shortness of breath, prolonged cough, breathlessness asthma, eye problems, difficulty in movements, tiredness and teeth problems, the upper class elderly, in view of their greater knowledge of illnesses, mentioned blood pressure, heart attacks, and diabetes which are largely diagnosed through clinical examination. In a study by (Mutharayappa and Bhat, 2008) NFHS-2 data was analysed to examine the type of lifestyle adopted by the elderly and its effects on their health conditions. "It was found that lifestyle adversely affects health and increases morbidity conditions among the elderly. Lifestyle habits such as alcohol consumption, regular smoking and tobacco chewing have adverse effects on one's ability to control diseases."

Some clinical studies have found that multiplicities of diseases are normal among the elderly and that a majority of the old are often ill with chronic bronchitis, anaemia, hypertension, digestive troubles, rheumatism, scabies and fever (Mutharayappa and Bhat, 2008). Some of the cases of disability among the elderly, as reported by a few medical studies, are difficulty in walking and standing, partial or complete blindness, partial deafness and difficulty in moving some joints, indigestion and mild breathlessness. The differential ageing phenomena, both physical and mental, appear to depend on environmental and social factors such as diet, type of education, adjustment to family and professional life, and consumption of tobacco and alcohol. Generally, when we compare the pre-and post retirement situation of health of the retired, it is seen that if a retired person keeps himself/herself fit before and immediately after his/her retirement, he/she can be free from illness during the post-retirement period; but once an illness starts, before or just after the retirement, he/she continues to face it during the post-retirement period. Based on a study of hospital data, (Pathak, 1982) has found that 62.6 per cent of the elderly patients had cardiovascular ailments, 42.4 per cent had gastrointestinal problems, 32.5per cent had uro-genital problems, 19.8 per cent had nervous breakdowns, 19.2 per cent had respiratory problems, 11.6 


\section{International Journal of Social Science and Economic Research}

ISSN: 2455-8834

Volume:06, Issue:02 "February 2021"

per cent had lymphatic problems, 7 per cent had high or low blood pressure, 11.2 percent had ear and eye problems, 4.8 per cent had orthopaedic problems, 5.7 per cent had surgical problems while 37.3 per cent of the elderly had problems with all their systems. Darshan and others(1987) have carried out a study of the elderly in various slums scattered in and around the city of Hissar. Among the 85 subjects interviewed by them, 67.1 per cent were sick at the time of the survey. Out of these, 73.7 per cent were suffering from chronic illness. (Gupta and Vohra, 1987) observed that only a few elderly with psychiatric disorders were being cared for in the inpatient wards in hospitals or as residents of homes. A recently conducted medico-social study of the urban elderly in Mumbai (S.Raju, 2002) has revealed that the influence of the factors such as educational status, economic status, age, marital status, perception on living status, addictions, degree of feeling idle, anxieties and worries, type of health centre visited and whether or not taking medicines, on both the perceived and actual health status of the elderly is found to be significant and varies considerably across different classes and sexes of the elderly.

Healthy aging is a lifelong concept that encompasses the mental, social and physical well-being of people and communities. Healthy communities address basic needs, promote optimal health and well-being, foster civic and social engagement and support the independence of the elderly. To accomplish this, a broad-based, collaborative approach is required of policymakers, service providers, businesses, civic and faith-based organizations, individuals and families.

\section{Life satisfaction in ageing after retirement}

The experience of retirement may vary with differing levels of access to social, cultural and economic resources that are important to life satisfaction. These factors include gender, age at retirement, social support, being in a relationship, general health, employment status before retirement, income levels after retirement and education.

\section{Gender}

Retiring men and women may experience different life course transitions and trajectories. Research has principally seen retirement as a predominantly male transition (Kim and Moen, 2001: 85). However, increases in women's labour force participation suggest that this does not reflect the current situation (Kim and Moen, 2001: 85). The labour force participation rate for women 55 years and over has increased from 12 percent in the 1980's to 27 percent in 2010 (ABS, 2010). Additionally, the progression from full-time employment to retirement has never been as clearly defined for women as it has been for men. There are a number of reasons for this.

Women may spend many years out of the workforce caring for others and may move in and out of the workforce more frequently as they juggle work and family roles (Warner-Smith et al., 2008). Therefore the transition from employment to retirement may not have a clearly defined 


\section{International Journal of Social Science and Economic Research}

ISSN: $2455-8834$

Volume:06, Issue:02 "February 2021"

effect on life satisfaction for women because they may have already adapted to changes in employment status earlier in the life course.

Finally women are disproportionately responsible for domestic labour in retirement compared to men and are disproportionately assigned a carers' role assisting sick or frail family members after retirement. Therefore women may have lower levels of life satisfaction than men due to having less autonomy over their free time in retirement.

\section{Life satisfaction and Age}

In the recent past, retirement from paid employment usually occurred for men at age 65 and for women at age 60, at which time they were probably eligible for the age pension. Retirement was often mandatory. Currently retirement age in Australia has become more variable. People can retire earlier or later and retirement is not mandatory in most organisations. The flexibility in retirement timing may mean that people have to make individual decisions about when they retire (Vaus and Wells, 2004). It is likely that variation in retirement age will be closely related to differences in other observable factors, such as socio-economic position and health status.

Retirement may be more detrimental to life satisfaction if it occurs unexpectedly, or "off-time" regarding either the institutionalised retirement age or an individuals own expectations and preferences (Szinovacz, 2003: 38). Early retirement may be associated with lower life satisfaction because of increased financial pressures and the overrepresentation of involuntary retirement and health problems among early retirees (Palmore et al., 1984; Williamson et al., 1992). (Gill et al, 2006) found that retirees below the conventional retirement age of 65 are more likely to have mental health problems relative to their working peer and retirees above this age (Gill et al., 2006).

\section{Social Support and Life satisfaction}

Social networks and support have been found to be predictors of positive well-being across the life course (Fratiglioni et al., 2000:Okabayashi et al., 2004). Social support and integration in the form of contact with family and friends have been found to facilitate a high level of life satisfaction after retirement (Taylor and Doverspike, 2003; Levitt et al., 1985; Hong and Duff, 1997). The composition of social networks with family members, friends, former co-workers and retired friends may change with retirement (Szinovacz, 2003). These new interactions with different people may offer retirees social support that may improve life satisfaction (Taylor and Doverspike, 2003). This may be particularly important because social networks developed while in the workforce may be suddenly removed (Moen et al., 2000). Research has found that women may be more likely than men to use retirement as an opportunity to increase their social activity (de Vaus and Wells, 2004). 
International Journal of Social Science and Economic Research

ISSN: 2455-8834

Volume:06, Issue:02 "February 2021"

\section{In a Relationship and Life Satisfaction}

Relationships are important to life satisfaction (Evans and Kelley, 2005; Evans and Kelley, 2004). Research has found that people who are married have higher levels of life satisfaction in retirement than those who are unmarried (Szinovacz, 2003; Atchley, 1992; Reitzes et al., 1996a; Seccombe and Lee, 1986). Thus we would expect that married or cohabitating people will have higher levels of life satisfaction across the retirement transition than those who are single, separated, widowed or divorced. With retirement there are changes to family structure, roles and responsibilities. Life satisfaction in retirement may be associated with an "empty nest", change of residence and the possible ill health and death of family members and friends. Research has found that retired men and women may become more involved with the lives of their children and grand children (Kremer, 1985; Szinovacz, 2003)

\section{Health and Life Satisfaction}

Health status is important to life satisfaction at all life stages, including in retirement. For people at retirement age, health problems are common and a great deal of unhappiness is the direct or indirect result of illness (Streib, 1956; Maddox, 1982). People who are healthier can make retirement adjustments more easily (Taylor and Doverspike, 2003; de Vaus and Wells, 2004). Being healthy may allow a greater diversity of activities and opportunities for access to social support. Ill health may be very disruptive to leisure and other satisfying social activities (Shultz et al., 1998).

\section{Being Employed before Retirement affecting life satisfaction}

One of the pre-retirement influences affecting how people adapt to the retirement transition is employment status. Retiring from paid work may be different from the transition to retirement while unemployed. Many people transition to retirement from unemployment due to the large proportion of unemployed people (ABS, 2010). Older people may have difficulties in finding work because of employer preference or because of rapid changes in technology. Being forced into involuntary retirement, may lead to low levels of life satisfaction. On the other hand, transitioning from unemployment to retirement may have a positive effect on life satisfaction due to the possible increase in income and feelings of security after becoming eligible for government or private pensions. The transition from unemployment to retirement may mean a positive role change after leaving the negatively experienced 'unemployment' status (Pinquart and Schindler, 2007).

Income Levels and life satisfaction 


\section{International Journal of Social Science and Economic Research}

ISSN: $2455-8834$

Volume:06, Issue:02 "February 2021"

Retirees with higher incomes, or at least adequate finances, report being more satisfied with life in retirement (Taylor and Doverspike, 2003; Seccombe and Lee, 1986; Crowley, 1986; Fillenbaum et al., 1985; George et al., 1984; Beehr, 1986; Beehr et al., 2000; Mutran et al., 1997; Taylor and Shore, 1995). In Australia, retirees may be self-funded or welfare reliant (Warren and Oguzoglu, 2010). Self funded retirees are people who have accumulated a certain level of superannuation in their working life. Welfare-reliant retirees are eligible for a means-tested aged pension. (Ong, 2009) found, in a study on prospective retirees who are approaching retirement age that self-funded retirees are more likely to have high educational qualification levels, to have experienced stable employment and to have a higher level of wealth while welfare-reliant retirees are likely to be older women who have gone through marital dissolution (Ong, 2009).

\section{Highest Level of Education}

Higher education is related to being employed and earning more (ABS, 2005). A high level of education may provide individuals with high levels of social skills and self-direction. Retirement can be an opportunity to follow meaningful and intrinsically satisfying activities (Reitzes and Mutran, 2004). However, the loss of status from being in a highly professional job before retirement may make the retirement adjustment more difficult.

\section{Method}

The aim of the study was to assess the health status and life satisfaction of professionally active and professionally inactive among the retired people. Descriptive research design is used as it is a scientific method which involves observing and describing the behavior of a subject without influencing it in any way. A descriptive study is one in which information is collected without changing the environment (i.e., nothing is manipulated). Sometimes these are referred to as "co relational" or "observational" studies.

Sample description: The total sample size taken was 30. The sample of 15 professionally active and 15 professionally inactive was collected among the retired people who were earlier in public sector jobs. People who are still engaged in some work after their retirement were taken as the sample of professionally active and people who were not engaged in any work were taken as the sample off professionally inactive. Purposive sampling was done because the aim of the study was to assess the health status and life satisfaction of professionally active and professionally inactive among the retired people.

Tool description: Health Status Questionnaire (HSQ) by Ware J Jr., KosinskiM , Keller A 12 item Short - Form health survey and Satisfaction With Life Scale developed by Diener, Emmons, Larsen \& Griffin(1985) was used. 
International Journal of Social Science and Economic Research

ISSN: 2455-8834

Volume:06, Issue:02 "February 2021"

Health Status Questionnaire (HSQ-12): Measuring health status as an indicator of individual, population, and community health is critical in reducing health disparities in populations. The purpose of this study was to test the psychometric properties of the Health Status Questionnaire12 (HSQ-12) Version 2.0, a brief self-reported health status instrument available within the public domain, in a low-income sample $(\mathrm{N}=7,793)$. The internal consistency reliability was .88 . Satisfaction With Life Scale

The Satisfaction with Life Scale is a five item scale that is designed around that one must ask subjects for an overall judgement of their life in order to measure the concept of life satisfaction. Individuals indicate their degree of agreement or disagreement on a 5- point Likert type scale. Score range from 5 to 25 with higher scores indicating greater life satisfaction.

\section{RESULT}

The aim of the study is to assess the health status and life satisfaction of professionally active and professionally inactive among the retired people.

Table no. 1: Shows the health status and life satisfaction of two groups i.e., professionally active and inactive retired people

\begin{tabular}{|l|c|c|c|}
\hline Group & $\mathrm{N}$ & Mean & S.D \\
\hline Active & 15 & 49.8 & 7.41 \\
Health Status & 15 & 45.26 & 7.69 \\
Inactive & 15 & 19.8 & 2.76 \\
\hline Active & 15 & 18 & \\
Life Satisfaction & 15 & 17.67 & 2.87 \\
Inactive & & & \\
\hline Active & 15 & 16.93 & 3.01 \\
Physical Health & & & \\
Inactive & & & \\
\hline
\end{tabular}


International Journal of Social Science and Economic Research

ISSN: 2455-8834

Volume:06, Issue:02 "February 2021"

\begin{tabular}{|l|c|c|c|}
\hline Active & 15 & 32.13 & 4.88 \\
Psychological Health & & & \\
Inactive & 15 & 28.33 & 5.25 \\
\hline
\end{tabular}

The above table indicates that the life satisfaction's mean score of professionally active $(M=19.8)$ is higher than the mean score of professionally inactive $(M=18.0)$. The health status mean score of professionally active $(\mathrm{M}=49.8)$ is higher than the mean score of professionally inactive $(\mathrm{M}=45.26)$.

The physical health mean score of professionally active $(\mathrm{M}=17.66)$ is higher than the mean score of professionally inactive ( $\mathrm{M}=16.93)$.

The psychological health mean score of professionally active $(\mathrm{M}=32.13)$ is higher than the mean score of professionally inactive ( $M=28.33)$.

Table no. 2 shows the correlation between the health status and life satisfaction

\begin{tabular}{|l|l|l|}
\hline Variables & Spearman Rho's & N \\
\hline Life Satisfaction & & \\
Health Status & $.67^{* *}$ & 30 \\
\hline
\end{tabular}

** Correlation is significant at the level 0.01 level (1- tailed)

The table no. 2 indicates the positive correlation of .66 between the health status and life satisfaction of two different groups. 
International Journal of Social Science and Economic Research

ISSN: 2455-8834

Volume:06, Issue:02 "February 2021"

Table 3 (a): shows mean difference on psychological health dimension between professionally active and inactive aged groups.

\begin{tabular}{|l|l|l|l|l|}
\hline Groups & Mean & $\mathrm{N}$ & $\begin{array}{l}\text { Mann- } \\
\text { Whitney } \\
\mathrm{U}\end{array}$ & $\begin{array}{l}\text { Level of } \\
\text { significance }\end{array}$ \\
\hline $\begin{array}{l}\text { Professionally } \\
\text { active }\end{array}$ & 32.13 & 15 & 61.00 & .03 \\
\hline $\begin{array}{l}\text { Professionally } \\
\text { inactive }\end{array}$ & 28.33 & 15 & & \\
\hline
\end{tabular}

The above table indicates the significant difference between the professionally active and inactive groups in terms of psychological health. Active group had better psychological health.

Table 3(b): shows mean difference on physical health dimension between professionally active and inactive aged groups.

\begin{tabular}{|l|c|c|l|l|}
\hline Groups & Mean & $\mathrm{N}$ & $\begin{array}{l}\text { Mann- } \\
\text { Whitney } \\
\text { U }\end{array}$ & $\begin{array}{l}\text { Level of } \\
\text { significance }\end{array}$ \\
\hline $\begin{array}{l}\text { Professionally } \\
\text { active }\end{array}$ & 17.67 & 15 & & .48 \\
\hline $\begin{array}{l}\text { Professionally } \\
\text { inactive }\end{array}$ & 16.93 & 15 & & \\
\end{tabular}


International Journal of Social Science and Economic Research

ISSN: 2455-8834

Volume:06, Issue:02 "February 2021"

The above table shows no significance difference in the physical health of professionally active and inactive groups.

Table no. 3(c): shows mean difference on life satisfaction between professionally active and inactive aged groups.

\begin{tabular}{|l|c|c|l|l|}
\hline Groups & Mean & N & $\begin{array}{l}\text { Mann- } \\
\text { Whitney } \\
\text { U }\end{array}$ & $\begin{array}{l}\text { Level of } \\
\text { significance }\end{array}$ \\
\hline $\begin{array}{l}\text { Professionally } \\
\text { active }\end{array}$ & 19.8 & 15 & 71.50 & .08 \\
\hline $\begin{array}{l}\text { Professionally } \\
\text { inactive }\end{array}$ & 18 & 15 & & \\
\hline
\end{tabular}

The above table shows no significant difference in the life satisfaction of professionally active and inactive groups.

\section{Discussion}

The aim of the present study was to assess the health status and life satisfaction of professionally active and professionally inactive among the retired people.By most measures, those working in retirement are doing quite well. Overall, they were satisfied with their lives, their jobs and their workplaces.

The result indicates the difference between the health status and life satisfaction of two groups i.e., professionally active and inactive retired people. The psychological health mean score of professionally active is significantly higher than the mean score of professionally inactive.

One of the researches by (Johnson, Catsouphes, Besen, Smyer, \&Matz-Costa, 2008) evaluated several factors contributed to the new trends in later retirement. The increase in the labour force participation of older workers reflects both societal shifts as well as changes in the lives of older workers. Economic conditions, occupation-specific labour force shortages, and new attitudes about aging and work have affected older workers' decisions about continued labour force participation. There have also been changes in the experience of older workers themselves that 


\section{International Journal of Social Science and Economic Research}

ISSN: $2455-8834$

Volume:06, Issue:02 "February 2021"

affect their decisions about work and retirement. The improved health status of older adults has increased life expectancy of both men and women. As a result, a greater percentage of older workers are physically able to continue to work. The assessments that older workers make about the adequacy of their financial resources affects their decisions as well. In fact, a minority of Baby Boomers (approximately one-quarter) report that they are very confident that they will have enough money to live comfortably in retirement.

In summary, older people are increasingly finding that they either want to work and/or they have work. Recent studies suggest that employment-particularly having a job that is a quality job and one that fits with the employees' priorities and preferences - contributes to the quality of life and life satisfaction of older workers. Life satisfaction has also been linked to employee's work behaviours, including job performance; therefore, life satisfaction is a topic of interest for organizations striving to be employers-of-choice.

Many studies are based on the fact that people who are working after retirement are healthier and satisfied with their life compared to the people who are not involved in any type of work after retirement. The meaning of retirement is usually bound up with the receipt of a pension whichis precisely why retired people are frequently referred to as 'pensioners'. In fact, it isoften claimed that pensions precede retirement in a historical sense. Until Otto vonBismarck's government gave birth to the first state pension in Germany in the 1880s,people generally worked until death. In practice, however, ill-health often prohibitedwork in the final years of life, leading to a reliance on younger relatives for support;and the wealthiest members of society obviously felt the compulsion to continueworking far less (Meadows, 2003). Bismarck himself only reluctantly retired atage 75, having fallen out of favour with Kaiser Wilhelm II; in any case, he would nothave qualified for a pension, given that it was available only to industrial workers, and introduced primarily to stem support for socialism (Bonoli, 2000).

Working retirees are changing how we think about careers. Traditionally, careers were conceptualized as a linear progression through a series of jobs, each with successively more responsibility. As findings outlined in this report demonstrate, however, the realities of the workforce and workplaces no longer fit with the notion of straight career "paths" or "ladders" with retirement representing one's final exit from the workforce.

\section{Conclusion}

The aim of the study is to assess the health status and life satisfaction between the professionally active and inactive retired people.. It proves that if the individual is satisfied in his/her life there health status will also be good. Life satisfaction is the way a person perceives how his or her life has been and how they feel about where it is going in the future. It is a measure of well-being 


\section{International Journal of Social Science and Economic Research}

ISSN: $2455-8834$

Volume:06, Issue:02 "February 2021"

and may be assessed in terms of mood, satisfaction with relations with others and with achieved goals, self-concepts, and self-perceived ability to cope with daily life. Positive Correlation indicates that the individual is satisfied in his/her life and maintains a good well being that is health. The individual who are satisfied and happy with their life pays more attention towards their health and growth.

Overall, it can be concluded that individuals who are professionally active have more significant level of health status, life satisfaction, physiological health and psychological health comparing with the individuals who are professionally inactive retired people. Further research needs to be carried out to asses other factors related to health status, life satisfaction, economical background.

\section{REFERENCES}

ABS (2010) '4102.0 - Australian Social Trends September, 2010', Australian Bureau of Statistics.

ABS (2005) '4102.0 - Australian Social Trends, 2005', Australian Bureau of Statistics.

Alam, Moneer, (2006). Ageing in India: Socio-economic and health dimensions. Academic Foundation, New Delhi.

Annamaria Lusardi (2009)., "Households Saving Behavior: The Role of Financial Literacy, Information, and Financial Education Programs," in Policymaking Insights From Behavioral Economics, ed. Christopher L. Foote, Lorenz Goette, and Stephan Meier.

Annamaria, Punam, \&Adam (2009). "New Ways to Make People Save: A Social Marketing Approach," in Overcoming the Saving Slump: How to Increase the Effectiveness of Financial Education and Saving Programs, ed. Annamaria Lusardi.

Annamaria\&Olivia (2011a). "Financial Literacy and Planning: Implications for Retirement WellBeing," in Financial Literacy: Implications for Retirement Security and the Financial Marketplace, ed. Olivia S. Mitchell and Annamaria Lusardi.

Adams, \&Beehr (nd.) Retirement: Reasons, Processes, and Results. New York: Springer Publishing Company.

Atchley, R.C. (1992) 'Retirement and marital satisfaction', pp. 145-58 in M. Szinovacz, D. Ekerdt and B.H. Vinick (eds) Families and retirement. Newbury Park, California: Sage.

Beehr, T.A. (1986) 'The process of retirement: A review and recomendations for future investigation', Personnel Psychology 39: 31-55.

Beehr, T.A., S. Glazer, N.L. Nielson \&S.J. Farmer (2000) 'Work and nonwork predictors of employees' retirement ages', Journal of Vocational Behavior57: 206-25. 
International Journal of Social Science and Economic Research

ISSN: 2455-8834

Volume:06, Issue:02 "February 2021"

Bonoli, G. (2000) The politics of pensions reform (Cambridge University Press).

Brown, M., Aumann, K., Catsouphes, M.P., Galinsky, E. \& Bond, J.T. (2010). Working in Retirement: A 21ST century Phenomenon. 2008 National Study of the Changing Workforce.

Crowley, J.E. (1985) 'Longitudinal Effects of Retirement on Men's Psycholgocial and Physical Well-Being', pp. 150-86 in H.S. Parnes, J.E. Haurin, R.J. Less, L.J. Morgan, W.R. Mott, F.L. Nestel and G. Nestel (eds) Retirement among American Men. Lexington, Massachusetts: Lexington Books.

Darshan, S., M.L. Sharma, \&S.P. Singh, (1987). 'Health needs of senior citizens', in: M.L.Sharma and T.M.Dak (eds.), Ageing in India: Challenge for the Society. Ajanta, Delhi, pp. 207-13.

Devi, N. Prabhavathy\&P. TamilarasiMurugesan, (2006). 'Institutional care for the elderly', Journal of the Indian Academy of Geriatrics, 2(1), March2006, pp. 15-20.

De Vaus, D. \&Y. Wells (2004) 'What should mature-age workers do to promote health and wellbeing in retirement?',Health Issues 80: 23-6.

Evans, M. \&J. Kelley (2005).Marital Biographies and Subjective Well Being: The Effect of De Facto Status Differs for the Never Married and the Divorced. The University of Melbourne: Melbourne Institute of Applied Economic and Social Research.

Fillenbaum, G.G., L.K. George \&E.B. Palmore (1985). 'Determinants and Consequences of Retirement', Journal of Gerontology 39: 364-71.

George, L.K. (1993). 'Sociological Perspectives on Life Transitions', Annual Review of Sociology 19: 353-73.

Fratiglioni, L., H.-X. Wang, K. Ericsson, M. Maytan\&B. Winblad (2000). 'Influence of Social Network on Occurrence of Dementia: A Community-based Longitudinal Study', The Lancet 355(9212): 1315-9.

Gill, S.C., P. Butterworth, B. Rodgers, K.J. Anstey, E. Villamil\&D. Melzer (2006). 'Mental health and the timing of Men's retirement ', Social Psychiatry and Psychiatric Epidemiology 41(7): 515-22.

Gore, M.S., (1990). Social factors affecting the health of the elderly, in R.L.Kane, J.G.Evans and Macfadyen (eds.) Improving the Health of Older People: a world view. Oxford University Press, New York.

Gore, M.S. (1996). 'Studying problems of ageing', unpublished paper presented at All-India Sociological Conference, 18 November, Shivaji University, Kolhapur. 


\section{International Journal of Social Science and Economic Research}

ISSN: $2455-8834$

Volume:06, Issue:02 "February 2021"

Gupta, Niharika, (1999). Two Papers and a Monograph of Field Practicum. TISS, Mimeo, Mumbai.

Hal Hershfield et al., (2011). "Increasing Saving BehaviorThrough Age- Progressed Renderings of the Future Self," Journal of Marketing Research 48, Special Issue, S23-37.

John Beshears et al., (2011). "The Effect of Providing Peer Information on Retirement Savings Decisions," National Bureau of Economic Research Working Paper 17345 (2011), accessed at www.nber.org/ papers/w17345.

Johnson, J.K. M., Catsouphes M.P., Bensen E., Smyer M., \& Costa C.M. (2008).Quality of Employment \& Life Satisfaction: A Relationship that matters for older workers.

Kim, J.E. \&P. Moen (2001). 'Is Retirement Good or Bad for Subjective Well-Being?',Current Directions in Psychological Science 10(3).

Kremer, Y. (1985). 'Parenthood and marital role performance among retired workers: Comparison between pre- and post-retirement period', Ageing and Society 5: 449-60.

Kumar, Vijay S., (1999). Quality of Life and Social Security for the Elderly in Rural India. Council for Social Development, Hyderabad.

Levitt, M.J., T.C. Antonucci, M.C. Clark, J. Rotten \&G.E. Finley (1985). 'Social support and well-being: Preliminary indicators based on two samples of the elderly', International Journal of Aging and Human Development 21: 61-77.

Hong, L.K. \&R.W. Duff (1997). 'Relative importance of spouses, children and friends in the life satisfaction of retirement community residents', Journal of Clinical Geropsychology3: 27582.

Maddox, H. (1982).Happiness, Lifestyle and Environment. Daylesford, Vic.: Freshet Press.

Meadows, P. (2003).Retirement ages in the UK (DTI).

Moen, P., V. Fields, H.E. Quick \&H. Hofmeister (2000). 'A life-course approach to retireemnt and social integration', in K. Pillemer, P. Moen, E. Wethington and N. Glasgow (eds) Social Integration in the Second Half of Life. Baltimore N.J.: John Hopkins University Press.

Mutharayappa, R. \&T.N. Bhat, (2008). 'Is lifestyle influencing morbidity among elderly?', Journal of Health Management, 10 (2),: pp.203-17.

Mutran, E.J., D.C. Reitzes\&M.E. Fernandez (1997). 'Factors that influence attitudes towards retirement', Research on Ageing 19: 251-73.

Okabayashi, H., J. Liang, N. Krause, H. Akiyama \&H. Sugisawa (2004). 'Mental Health Among Older Adults in Japan: Do Sources of Social Support and Negative Interaction make a Difference? ', Social Science and Medicine 59: 2259-70. 


\section{International Journal of Social Science and Economic Research}

ISSN: $2455-8834$

Volume:06, Issue:02 "February 2021"

Ong, R. (2009). 'Self-provision in retirement: Quantitative evidence on older Australians' expectations and experiences', Australasian Journal on Ageing 28(1): 22-7.

Palmore, E.B., G.G. Fillenbaum\&L.K. George (1984). 'Consequences of Retirement', Journal of Gerontology 39(1): 109-16.

Pathak, J.D., (1975). Inquiry into Disorders of the Old. Part I: Medical Research Centre, Bombay Hospital Trust, Bombay.

Pathak. J.D., (1982). 'Health problems of the Elderly in India' in K.G.Desai (ed.) Ageing in India, Tata Institute of Social Sciences, Bombay pp. 43-53.

Patrick J. Bayer, B. Douglas Bernheim, \&Scholz, J.K. (2009). "The Effects of Financial Education in the Workplace: Evidence From a Survey of Employers," Economic Inquiry 47, no. $4,605-24$.

Pinquart, M. \&I. Schindler (2007). 'Changes in Life Satisfaction in the Transition to Retirement : A Latent-Class Approach', Psychology and Aging 22(3): 442-55.

Prakash, I.J., (2005). Ageing in India: retrospect and prospect. Bangalore University, Bangalore.

Rajan, I.S., Carla R. \&Myrtle P., (2008). Institutional Provisions and Care for the Elderly.,Perspectives from Asia and Europe. Anthem Press, New Delhi.

Reitzes, D.C., E.J. Mutran\&Fernandez, M.E. (1996a) 'Preretirement Influences on Postretirment Self-Esteem', Journal of Gerontology: Social Sciences 51B: S242-S9.

Reitzes, D.C. \&Mutran E.J. (2004) 'TheTranistion to Retirement: Stages and Factors that Influence Retirement Adjustment', International Journal of Aging and Human Development 59(1): 63-84.

Robert S., Douglas H.\&Joy J.L. (2007). "Goal Clarity and Financial Planning Activities as Determinants of Retirement Savings Contributions," International Journal of Aging and Human Development 64, no. 1, 13-32.

Saldanha D., Maj. R.M., Srivastava K., GoyalS. \&BhattacharyaD., (2010). An epidemiological study of dementia under the aegis of mental health program, Maharashtra, Pune chapter. Indian Journal of Psychiatry. 52(2). pp. 131-39.

Seccombe, K. \&G.R. Lee (1986) 'Gender Differences in Retirement Satisfaction and its Antecedents', Research on Ageing 8: 426-40.

Shultz, K.S., K.R. Morton \&J.R. Weckerle (1998). 'Influence of Push and Pull Factors Voluntary and Involuntary Early Retirees' Retirement Decision and Adjustment', Journal of Vocational Behavior53: 45-57. 
International Journal of Social Science and Economic Research

ISSN: 2455-8834

Volume:06, Issue:02 "February 2021"

Siva Raju, S., (2002). Health Status of the Urban Elderly: a medico-social study, B. R. Publishing Co., Delhi.

Siva Raju, S., (2002). "Meeting the Needs of the Poor and Excluded in India', Situation and Voices. The Older Poor and Excluded in South Africa and India, UNFPA, Population and Development Strategies, 2, pp. 93-110.

Streib, G.F. (1956) 'Morale of the Retired', Social Problems 3(4): 270-6.

Szinovacz, M.E. (2003) 'Contexts and pathways: Retirement as institution, process, and experience', pp. 6-52 in G.A. Adams and T.A. Beehr (eds) Retirement: Reasons, Processes, and Results. New York: Springer Publishing Company.

Taylor, M.A. \&L.F. Shore (1995). 'Predictors of planned retireemnt age: An application of Beehr's model', Psychology and Aging 10(1): 76-83.

Taylor, M.A. \& D. Doverspike (2003). 'Retirement Planning and Preparation', pp. 53-82 in

Vasantha Devi K.P. \& S. Premakumar. (2000). Health and nutritional problems of the aged in Sudhir, M.A.(ed.) Ageing in Rural India: perspectives and prospects. Indian Publishers and Distributors, Delhi.

Warner-Smith, P. J., Powers \& A. Hampson (2008). 'Women's experiences of paid work and planning for retirement', Office for Women, Department of Families, Community Services and Indigenous Affairs.

Warren, D. \&Oguzoglu, U. (2010). 'Retirement in Australia: A Closer Look at the Financial Incentives', The Australian Economic Review 43(4): 357-75.

Wason, Neelam\& Jain, (2011). Malnutrition and Risk of Malnutrition among Elderly, Indian Journal of Gerontology, 25(2). pp. 208-17.

Williamson, R.C., A.D. Rinehart \&Blank, T.O. (1992).Early retirement : promises and pitfalls. New York ; London: Plenum.

UNFPA - Population and Family Study Centre, (1999). Population Ageing: challenges for policies and programmes in developed and developing countries. UNFPA and Population and Family Study Centre New York andBrussels. 